\title{
Mapping of Waste Water Sources in the City of Manado and Alternative Solutions
}

\author{
T K Londa, F F Warouw, P H Pusung
}

\begin{abstract}
The problem of wastewater is a serious problem to overcome. Pollution of rivers, waterways, wells, and the sea is increasing due to the increase in community activities. This condition is a serious challenge in the context of developing Manado as a world tourism city. This study aims to identify the location of waste water accumulation, by tracing the source of waste. This information is traced through the RTRW map and the Manado City masterplan. The study of wastewater management in the city of Manado is based on population density maps. The results of the mapping show the level of waste sources starting from a density level of less than 100 people / ha (Model A), a density level of 100-300 People / Ha (Model B), and a density level of more than 300 People / Ha (Model C). The alternative conclusions for solving the problem of Area A wastewater treatment are in place while the waste from the bathroom, kitchen and washing water may be disposed of without treatment. Area B of other household wastes must be processed by processing on-site to a certain degree of processing, which is to reach a BOD concentration of $60 \mathrm{mg} /$ liter. Area C of all household wastewater will be processed in a centralized manner, namely the riolization system to a certain degree of processing so that the $\mathrm{BOD}$ concentration that exits is maximum of $30 \mathrm{mg} /$ liter.
\end{abstract}

Index Terms: Pemetaan, Air Limbah,,Sumber, Kota Manado

\section{INTRODUCTION}

Manado The problem of environmental pollution in urban areas, such as in the city of Manado, has shown quite serious symptoms, especially the problem of water pollution. The cause of pollution does not only originate from industrial waste which simply throws away waste water without processing it into the river or sea [1]. Pollution is also determined by the city community itself either intentionally or not. As a result of household wastewater whose numbers are getting bigger every day in accordance with the development of the population, the pollution is increasingly real [1]. The low awareness of some people who directly dispose of feces and garbage into the river, causes the process of pollution of existing rivers to increase rapidly [3].

The greater rate of population development and industrialization has resulted in a decrease in the quality of the environment. The density of settlements and poor conditions of environmental sanitation and industrial discharges which are directly discharged into water bodies without processing have caused river pollution [4]. Not only

\section{Revised Manuscript Received on September 22, 2019.}

T K Londa, Universitas Negeri Manado, Tondano, 95618, Indonesia. treesjelonda@unima.ac.id

F F Warouw, Universitas Negeri Manado, Tondano, 95618, Indonesia

P H Pusung, Institut Pemerintahan Dalam Negeri, Tampusu, 95618, Indonesia rivers but shallow ground water in part and coastal cities will have an impact due to existing pollution.

The wastewater of major cities in Indonesia can be broadly divided into three, namely industrial wastewater and domestic wastewater which is derived from household waste and the third is wastewater from offices and shops (commercial areas). At present in addition to pollution due to industrial waste, pollution due to domestic waste has shown a quite serious level[5].

The city of Manado, for example, as a result of the lack of sewerage system results in contamination of river bodies by domestic waste water, even river bodies designated as raw material for mineral water have also been polluted. Problems of pollution by household wastewater in Manado City area is further exacerbated due to the development of residential locations in the buffer zones around Manado, which are not equipped with wastewater treatment facilities, so that all waste water is discharged into public channels and eventually flows to river bodies in the City area Manado.

\section{METHOD}

The purpose of this paper is to identify water pollution problems in the city of Manado and provide an alternative response to processing problems, especially regarding household waste. The target to be achieved is to improve the quality of water entering the river body in the city of Manado. This study focuses on parts of residential areas, sunagi areas and coastal areas. This was concluded in accordance with the observations on the Manado city map. The results of the research data were obtained by conducting observations and interviews on 17 August 2018. The city of Manado as the capital city of North Sulawesi Province experienced rapid development changes with a population of 427,906 people, extensive land area of 15,726 hectares. Government administration consists of 11 sub-districts, 87 sub-districts and 504 neighborhoods [6].

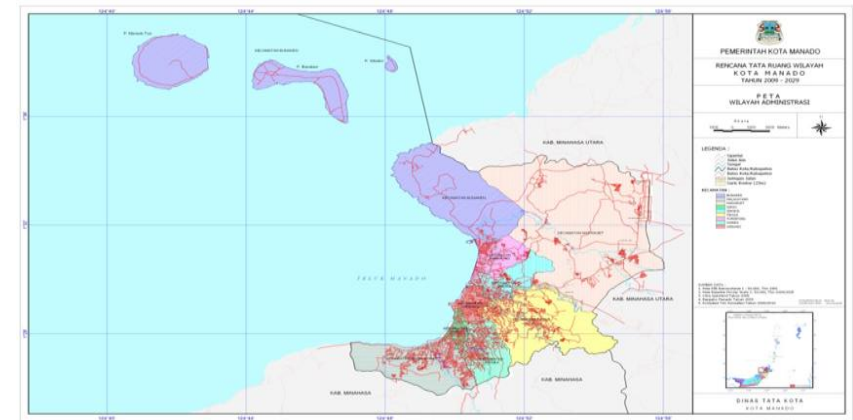

Fig 1. Map of Research Location

Source: Manado City Spatial Plan 2011 - 2031) 


\section{ANALYSE AND INTERPRETATION}

\section{A. Mapping Based on Geographical Conditions.}

\section{1) a. River City Conditions in Manado}

According to the standards of water quality standards based on PP No. 82 of 2001 concerning BOD Quality threshold of $12 \mathrm{mg} / \mathrm{L}$ [10]. There are river BOD concentrations in Manado (Table 1), namely Bailang River 2 mg / L, Maasing River 17.6 mg / L and Sungai Tondano 4 $\mathrm{mg} / \mathrm{L}$. The high concentration of BOD in the Maasing River is influenced by the amount of household waste effluents through sewers entering the river flow. The high concentration of BOD in the waters of the Maasing River is in line with the smell of foul odor in the waters of the river, which is caused by hydrogen sulfide $\left(\mathrm{H}_{2} \mathrm{~S}\right)$ and phosphorus. The emergence of this gas as a result of the low concentration of oxygen in it or even already exhausted, so that aerobic bacteria will die all (Paytan and Mclaughlin, 2007 in Susana and Suyarso, 2008). Lee et al. (1978 in Wijayanti, 2007) stated that waters containing BOD more than $10 \mathrm{mg} / \mathrm{L}$ meant that the waters had been polluted by organic matter, whereas if below $3 \mathrm{mg} / \mathrm{L}$ meant that the waters were still quite clean. When viewed from the BOD parameter, the existence of the Maasing River has been polluted by organic matter, the Todano River is lightly polluted by organic matter and the Bailang River can be categorized as fairly clean waters [7].

Table 1: Status of River Water Quality in the City of Manado

\begin{tabular}{|c|c|c|c|c|c|c|c|}
\hline \multirow{2}{*}{ Parameter } & \multirow{2}{*}{ Lokasi } & \multirow{2}{*}{ Hasil } & \multicolumn{4}{|c|}{ Baku Mutu* } & \multirow{2}{*}{ Status } \\
\hline & & & 1 & II & III & IV & \\
\hline \multirow{3}{*}{$\mathrm{BOD}(\mathrm{mg} / \mathrm{L})$} & S.Bailang & 2 & \multirow{3}{*}{2} & \multirow{3}{*}{3} & \multirow{3}{*}{6} & \multirow{3}{*}{12} & LS \\
\hline & S.Maasing & 17,67 & & & & & TLS \\
\hline & S. Tondano & & & & & & TL I,II \\
\hline \multirow[b]{2}{*}{$\mathrm{NO}_{3}-\mathrm{N}(\mathrm{mg} / \mathrm{L})$} & S.Bailang & 0,388 & \multirow[b]{2}{*}{10} & \multirow[b]{2}{*}{10} & \multirow{2}{*}{20} & \multirow[b]{2}{*}{20} & \\
\hline & S.Maasing & 0,029 & & & & & $L S$ \\
\hline \multirow[b]{2}{*}{$\mathrm{PO}_{4}-\mathrm{P}(\mathrm{mg} / \mathrm{L})$} & S.Bailang & 0,104 & \multirow[b]{2}{*}{0,2} & \multirow[b]{2}{*}{0,2} & \multirow[b]{2}{*}{1} & \multirow[b]{2}{*}{5} & LS \\
\hline & $\begin{array}{l}\text { S.Maasing } \\
\text { S.Tondano }\end{array}$ & $\begin{array}{l}1,858 \\
0,289\end{array}$ & & & & & $\frac{T L I, I I, \| 1}{T L 1, \|}$ \\
\hline \multicolumn{8}{|l|}{ Keterangan } \\
\hline \multicolumn{8}{|c|}{$\begin{array}{l}\text { * PP RI, No. } 82.2001 \text {, tentang Pe } \\
\text { LS : Layak untuk semua } \\
\text { TL : Tidak layak untuk } \\
\text { TLS: Tidak layak untuk semua }\end{array}$} \\
\hline a. Kelas I & \multirow{2}{*}{\multicolumn{7}{|c|}{$\begin{array}{l}\text { Air yang peruntukannya dapat digunakan untuk air baku air minum dan peruntukan } \\
\text { lain dengan syarat kualiltas yang sama } \\
\text { Air yang peruntukannya dapat digunakan untuk prasarana/sarana rekreasi air, } \\
\text { pembudidaayan ikan air tawar, peternakan, pertanaman dan peruntukan lain dengan } \\
\text { syarat kualitas yang sama }\end{array}$}} \\
\hline b. Kelas II & & & & & & & \\
\hline c. Kelas III & \multicolumn{7}{|c|}{$\begin{array}{l}\text { Air yang peruntukannya dapat digunakan untuk pembudidayaan ikan air tawar, } \\
\text { peternakan, air untuk mengairi pertanaman, air industri, air pertambangan dan }\end{array}$} \\
\hline d. Kelas IV : & \multicolumn{7}{|c|}{$\begin{array}{l}\text { Air yang peruntukannya dapat digunakan untuk mengairi pertanaman, air industri, air } \\
\text { pertambangan dan peruntukan lain dengan syarat kualitas yang sama. }\end{array}$} \\
\hline
\end{tabular}

\section{2) Kondisi Air Tanah Kota Manado}

The quality of ground water for springs and village wells turned out that the total coliform content of 17 and 27 APM / $100 \mathrm{ml}$ and drill wells of 2 APM / 100ml had exceeded the quality standard according to Permenkes No. 492 in 2010. Geographically the location of the groundwater extraction point for village wells as shown on the map of the Sumompo TPA sampling point location is 1031 '15.2 "North Latitude and 1240 51' 42.3' ' East Longitude.

Based on Minister of Health Regulation No. 492 of 2010 concerning drinking water quality requirements and laboratory analysis results, the parameters used to determine groundwater quality are: Color, Turbidity, Odor, Temperature, pH, TDS, Nitrate, Coliform. For each

parameter of groundwater quality, yield and quality standards respectively can be seen in table 2 . The results of (Table.2) show the number of coliforms has a high enough number of quality standards ranging from 27 APM / 100ml for estimates of village water quality in the research area as a comparison material in accordance with Minister of Health Regulation no. 492 of 2010 concerning Drinking Water Quality Requirements.

It is suspected that the high coliform content is caused by livestock activities carried out by residents around the wells and other activities, for example the suspension of livestock waste and the distance of septic tanks from residents' wells and open wells without special handling [8].

Table 2: Groundwater Test Results

\begin{tabular}{cccc}
\hline Parameter & Satuan & Hasil & Baku Mutu* $^{*}$ \\
\hline Warna & Pt-Co & 1 & 15 \\
Kekeruhan & NTU & 0,1 & 5 \\
Bau & - & Tidak berbau & Tidak berbau \\
Suhu & ${ }^{0} \mathrm{C}$ & 26,0 & Suhu udara \pm 3 \\
$\mathrm{pH}$ & - & 6,90 & $6,5-8,5$ \\
BOD & $\mathrm{mg} / \mathrm{mg}$ & 35 & - \\
COD & $\mathrm{mg} /$ & 62 & - \\
TSS & $\mathrm{mg} / \mathrm{l}$ & 10 & - \\
TDS & $\mathrm{mg} / \mathrm{l}$ & 420 & 500 \\
Nitrat & $\mathrm{mg} / \mathrm{l}$ & 15,87 & 50 \\
Coliform & APM/100ml & 27 & 0
\end{tabular}

Sumber: Hasil Uji Lab.Standarisasi Industri Manado 2016

3) The condition of the Gulf of Manado Coast

The entire river flowing in the city of Manado empties into the waters of the Gulf of Manado, so that the quality of the water is greatly influenced by the condition of the quality of the river flowing into the Manado Bay. With the worse quality of river water flowing in the Manado region, the condition of water quality in the Bay of Manado is also getting worse.

This is illustrated by the results of the research described below. Salinity levels have an average value of $26.63 \%$ o, Sea water temperature has an average value of $30 \mathrm{oC}, \mathrm{pH}$ of seawater has an average value of 8.68. The standard value of $\mathrm{pH}$ quality is based on Government Regulation No. 82 of 2001 concerning Management of Water Quality and Water Pollution Control of 7 - 8.5, sea water BOD has an average value of $40.33 \mathrm{mg} / 1$. The BOD quality standard value based on the Decree of the Minister of Environment No. 51 of 2004 concerning Sea Water Quality Standards of $10 \mathrm{mg} / \mathrm{1}$, sea water COD on the coast of Manado Bay has an average value of $661.33 \mathrm{mg} / \mathrm{l}$. COD quality standard values based on Government Regulation No. 82 of 2001 concerning Management of Water Quality and Water Pollution Control by $25 \mathrm{mg} / 1$, DO sea water on the coast of the Gulf of Manado has an average value of $7.65 \mathrm{mg} / 1$. The quality standard DO based on the Decree of the Minister of Environment No. 51 of 2004 concerning Sea Water Quality Standards of $>5 \mathrm{mg} / \mathrm{L}$ [9] 
Table 3: Hasil Uji Kualitas Air Teluk Manado

\begin{tabular}{|c|c|c|c|c|c|c|c|c|c|}
\hline & Koordinat & $\begin{array}{l}\text { Suhu } \\
\left({ }^{\circ} \mathrm{C}\right)\end{array}$ & pH & $\begin{array}{c}\text { Salinitas } \\
(\% a)\end{array}$ & $\begin{array}{l}\text { BOD } \\
(\mathrm{mg} / \mathrm{l})\end{array}$ & $\begin{array}{l}\text { COD } \\
(\mathrm{mg} / \mathrm{l})\end{array}$ & $\begin{array}{c}\text { DO } \\
(\mathrm{mg} / \mathrm{l})\end{array}$ & $\begin{array}{c}\mathrm{N} \\
(\mathrm{mg} / \mathrm{l})\end{array}$ & $\begin{array}{c}\mathrm{P} \\
(\mathrm{mg} / \mathrm{l})\end{array}$ \\
\hline Titik 1 & $\begin{array}{l}\text { N } 01^{\circ} 27.607^{\prime} \& \\
\text { E } 124^{\circ} 47.618^{\prime}\end{array}$ & 30,1 & 8,46 & 26,7 & 37 & 666 & 6,35 & $\begin{array}{c}2,377 \\
1\end{array}$ & 0,0217 \\
\hline Titik 2 & $\begin{array}{l}\mathrm{N} 01^{\circ} 27.601^{\prime} \& \\
\text { E } 124^{\circ} 47.617^{\circ}\end{array}$ & 30 & 8,63 & 29,9 & 47 & 649 & 8,21 & $\begin{array}{c}2,558 \\
8\end{array}$ & 0,1997 \\
\hline Titik 3 & $\begin{array}{l}\text { N } 01^{\circ} 27.605^{\prime} \& \\
\text { E } 124^{\circ} 47.6266^{\prime}\end{array}$ & 29,9 & 8,65 & 23,3 & 37 & 669 & 8,39 & $\begin{array}{c}2,165 \\
4\end{array}$ & 0,04 \\
\hline Rerata & & 30 & 8,58 & 26,63 & 40,33 & $\begin{array}{c}661,3 \\
3\end{array}$ & 7,65 & $\begin{array}{c}2,367 \\
1\end{array}$ & $\begin{array}{c}0,0871 \\
3\end{array}$ \\
\hline $\begin{array}{l}\text { Baku } \\
\text { Mutu }\end{array}$ & & $25-30$ & $7-8,5$ & $30-40$ & 10 & 25 & $>5$ & 0,008 & 0,015 \\
\hline
\end{tabular}

Sumber: Hasil Uji Lab.Standarisasi Industri Manado 2016

\section{B. Mapping Based on Population Density.}

The impact of building developments and population density is the growth of slums that cannot be avoided in line with the needs of the people in Manado City. In addition to slums, the impact of the condition of building growth and population density is congestion, increasing volumes of waste, liquid waste, unemployment rates and many more problems due to the population impact behind the successful development of the city of Manado. Judging from the characteristics of settlements.

Table 2: Population and Density of the City of Manado

\begin{tabular}{|l|l|l|l|l|l|}
\hline $\begin{array}{l}\text { Subdist } \\
\text { rict }\end{array}$ & Male & Female & Total & $\begin{array}{l}\text { Urutan } \\
\text { Penduduk }\end{array}$ & $\begin{array}{l}\text { Urutan } \\
\text { Kepada } \\
\text { tan }\end{array}$ \\
\hline $\begin{array}{l}\text { Malalay } \\
\text { ang }\end{array}$ & 29.010 & 28.309 & 57.319 & $\mathbf{( 1 )}$ & \\
\hline Sario & 12.300 & 12.156 & 24.456 & & \\
\hline Wanea & 28.029 & 28.480 & 56.509 & $\mathbf{( 2 )}$ & \\
\hline Wenang & 17.822 & 18.209 & 36.031 & & \\
\hline Tikala & 14.912 & 14.781 & 29.693 & & $(\mathbf{2})$ \\
\hline $\begin{array}{l}\text { Paal } \\
\text { Dua }\end{array}$ & 21.169 & 21.319 & 42.488 & & \\
\hline $\begin{array}{l}\text { Mapang } \\
\text { et }\end{array}$ & 26.772 & 26.944 & 53.716 & $\mathbf{( 3 )}$ & \\
\hline Singkil & 25.017 & 23.231 & 48.248 & & $\mathbf{( 1 )}$ \\
\hline $\begin{array}{l}\text { Tuminti } \\
\text { ng }\end{array}$ & 25.729 & 25.810 & 51.539 & & $\mathbf{( 3 )}$ \\
\hline $\begin{array}{l}\text { Bunake } \\
\mathrm{n}\end{array}$ & 10.787 & 10.953 & 21.740 & & \\
\hline $\begin{array}{l}\text { Bunake } \\
\mathrm{n} \\
\text { Kepulau } \\
\text { an }\end{array}$ & 3.187 & 2.980 & 6.167 & & \\
\hline Total & 214.734 & 213.172 & 427.906 & & \\
\hline
\end{tabular}

\section{RESULT AND DISCUSSION}

From the two mapping analyzes above, an analysis of alternative solutions for waste water management in the city of Manado was carried out. Ideas concerning alternative solutions to waste water management based on the above mapping. (1) Condition Mapping and (2) Population Mapping. It was concluded that the management of wastewater in the city of Manado needs to be based on population density. This is due to the fact that population density (population) is the most dominant factor in contributing to water pollution in the city of Manado. The alternative solutions for solving wastewater problems are as follows:

\section{A. Low Population Areas (Manage A Model)}

What is meant by a region with a low population density is an area with a population density not exceeding 100 people per hectare. For this area only waste from toilets must be treated by processing on-site (ON SITE TREATMENT) while waste from the bathroom, kitchen and washing water may be disposed of without treatment.

\section{B. Regions with Moderate Population Density (Model B Management)}

Namely areas with population densities between 100 to 300 people per hectare. In this area, waste water from toilets and other household wastewater must be processed by on site treatment to a certain degree of processing, which is to reach a BOD concentration of $60 \mathrm{mg} /$ liter.

\section{Areas with High Population Density (Manage Model C)}

Is a region with a population density greater than 300 people per hectare. In this area, all household wastewater will be processed in a centralized manner, namely the riolization system (sewerage system) to a certain degree of processing so that the BOD concentration that exits is a maximum of $30 \mathrm{mg} /$ liter.

\section{CONCLUSION}

From the above discussion it can be concluded: Mapping of waste water sources is one of the strategies in environmental management directly from the source at the community level. This mapping is to provide information for the community and to invite the public to care about environmental sustainability; Based on the results of the research and discussion of the following:

a. Waste can be traced to sources based on geographical conditions and population density

b. Integration of both can make it easier for us to find alternative solutions to the problem of waste.

\section{ACKNOWLEDGEMENTS}

The results of the research on the mapping of wastewater sources in the city of Manado along with alternative solutions have been arranged. For these results, the author would like to thank all those who have participated in the implementation of this research. Thanks also to those involved in formulating research results and their implications for the three pillars of sustainable development, namely social, economic and environmental. In the end, with this mapping, the ultimate goal of environmental sustainability and improving the economy of the community can be achieved by not ignoring environmental sustainability. 


\section{REFERENCES}

[1] Anderson, J. (2003). The environmental benefits of water recycling and reuse. Water Science and Technology: Water Supply, 3(4), 1-10.

[2] Hill, M. K. (2010). Understanding environmental pollution. Cambridge University Press.

[3] Rose, J. B., Epstein, P. R., Lipp, E. K., Sherman, B. H., Bernard, S. M., \&Patz, J. A. (2001). Climate variability and change in the United States: potential impacts on water-and foodborne diseases caused by microbiologic agents. Environmental health perspectives, 109(Suppl 2), 211.

[4] Bolong, N., Ismail, A. F., Salim, M. R., \& Matsuura, T. (2009). A review of the effects of emerging contaminants in wastewater and options for their removal. Desalination, 239(1-3), 229-246.

[5] Brook, R. D., Franklin, B., Cascio, W., Hong, Y., Howard, G., Lipsett, M., ...\&Tager, I. (2004). Air pollution and cardiovascular disease: a statement for healthcare professionals from the Expert Panel on Population and Prevention Science of the American Heart Association. Circulation, 109(21), 2655-2671.

[6] Manado, B. P. S. K. (2016). Manado DalamAngka.

[7] Tarigan, A., Lasut, M. T., \&Tilaar, S. O. (2013). KajianKualitasLimbahCairDomestik di Beberapa Sungai yang Melintasi Kota Manado dariAspekBahanOrganikdanAnorganik. JurnalPesisirdanLautTropis, 1(1), 55-6.

[8] Su, M. I., Warouw, V. R. C., \&Theffie, K. L. (2017, May). AnalisisKualitas Air DisekitarSitusTpaSumompo Kota Manado. In Cocos (Vol. 1, No. 5).

[9] Sritennaya A.P Iskandar, Rahayu H. Akil, Woodford B.S. Joseph(2016)Analisis Pencemaran Organik Di Pantai Malalayang II Kota Manado Tahun 2016Fakultas Kesehatan Masyarakat Universitas Sam Ratulang

\section{AUTHOR PROFILE}

T K Londa

Currently I am affiliated with Universitas Negeri Manado, Tondano, 95618, Indonesia. My area of research is sustainability.

\section{F F Warouw}

Currently I am affiliated with Universitas Negeri Manado, Tondano, 95618, Indonesia and my area of research is sustainability.

P H Pusung

I am affiliated with Institut Pemerintahan Dalam Negeri, Tampusu, 95618 , Indonesia my area of research is sustainability. 